DOI 10.46916/15102020-8-978-5-00174-015-5

\title{
К ВОПРОСУ О ВОЗМОЖНОСТЯХ КИОКУСИНКАЙ КАК ОДНОГО ИЗ ВИДОВ ВОСТОЧНЫХ ЕДИНОБОРСТВ В КОРРЕКЦИИ НАРУШЕНИЙ ПРОИЗВОЛЬНОЙ РЕГУЛЯЦИИ СЛАБОСЛЫШАЩИХ ДЕТЕЙ
}

Грачев Михаил Расулович

аспирант кафедры адаптивной физкультуры ТГУ им. Г. Р. Державина, педагог-организатор Спортивно-педагогического колледжа Москомспорта, г. Москва

Аннотация: В статье рассматривается вопрос коррекции нарушений произвольной регуляции у слабослышащих детей с помощью занятий Киокусинкай - одного из видов восточных единоборств. Автор статьи, чемпион мира по данному виду спорта, разработал свою методику занятий Киокусинкай со слабослышащими детьми. Известно, что восточные единоборства - это прежде всего особая философия, способная нивелировать тот возрастной нигилизм, что, как правило, формируется у слабослышащих подростков.

Парциальная несформированность когнитивного компонента познавательной деятельности, и прежде всего, недоразвитие речи, является одной из наиболее серьезных причин нарушения произвольности двигательной активности слабослышащих детей. Методика, предлагаемая автором, позволяет корректировать эти нарушения.

Ключевые слова: проблема произвольной регуляции, коррекция нарушений произвольной регуляции, философия и техники Киокусинкай, методика занятий Киокусинкай со слабослышащими детьми, парциальная несформированность когнитивного компонента, познавательная деятельность, нарушения произвольности двигательной активности, поведенческий нигилизм, недоразвитие речи.

\section{TO THE QUESTION OF THE POSSIBILITIES OF KYOKUSHINKAI AS ONE OF THE TYPES OF ORIENTAL MARTIAL ARTS IN THE CORRECTION OF DISORDERS OF VOLUNTARY REGULATION OF HEARING-IMPAIRED CHILDREN}

\section{Grachev Mikhail Rasulovich}

\footnotetext{
Abstract: The article discusses the issue of correcting violations of voluntary regulation in hearing-impaired children with the help of Kyokushinkai classes - one 
of the types of oriental martial arts. The author of the article, the world champion in this sport, has developed his own method of training Kyokushin with hearing impaired children. It is known that martial arts is, first of all, a special philosophy capable of leveling the age-related nihilism that, as a rule, is formed in adolescents with hearing impairments.

Partial lack of formation of the cognitive component of cognitive activity, and first of all, speech underdevelopment, is one of the most serious reasons for impaired voluntary motor activity in hearing-impaired children. The technique proposed by the author allows you to correct these violations.

Key words: problem of voluntary regulation, correction of voluntary regulation disorders, philosophy and technology of Kyokushin, Kyokushin training method for hearing-impaired children, partial lack of formation of the cognietive component, cognitive activity, impaired voluntary movement, behavioral nihilism, speech underdevelopment.

Потеря слуха в детском возрасте тесно связана с нарушениями в развитии речевой функции ребенка и, как следствие, в той или иной степени деформацией интеллекта. Согласно статистике, на каждую тысячу новорожденных приходится один слабослышащий. Однако с каждым годом численность слабослышащих детей на каждую тысячу увеличивается вследствие перенесенных инфекционных заболеваний, из-за лечения препаратами, давшими осложнения на слух, в связи с механическими травмами и т.п.

Слабослышащие дети, в отличие от глухих, способны накапливать минимальный запас слов, хотя слова эти неизбежно оказываются искаженными по своему фонетическому звучанию, оказывая необратимое влияние на восприятие слабослышащим ребенком окружающего социума.

В контексте проблемы отметим, что в работах отечественных ученых М.М. Нудельман, М.Ю. Рау, Е.А. Сошиной и др. убедительно доказывается: проблема взаимоотношений слабослышащего ребенка и окружающего его мира, взаимоотношений со сверстниками и взрослыми особенно актуальна сегодня. Хотя бы потому, что, по данным Росстата, ежегодно увеличивается число рождающихся глухих и слабослышащих детей [1, С. 23-27].

Произвольная регуляция деятельности, как известно, лежит в основе человека в любом возрасте, но ее сформированность у ребенка старшего дошкольного - младшего школьного возраста имеет особое значение, 
поскольку именно в период от 5 до 8-9 лет дети переживают стремительную динамику произвольной регуляции[2, С.31-54]. Выдающийся отечественный ученый Л. С. Выготский в своих трудах охарактеризовал этот отрезок жизни ребенка как «возраст утраты непосредственности», поскольку основополагающее его новообразование - появление в поведении интеллектуального начала: своеобразного «буфера» между переживанием и самим поступком. В научной литературе данная особенность формирования произвольной регуляции получила название «кризиса семи лет». Хотя на самом деле качественные изменения, которыми сопровождается этот процесс, наблюдаются до 10-11 лет [3, C.376-385].

Вопрос формирования произвольной регуляции неразрывно связан с проблемой ее нарушений. Отправной точкой исследования механизмов обозначенной проблемы является изучение кризисных, переломных моментов в жизни человека. То есть тех моментов, когда, по мнению М.Ш. Вроно [10, C. 16-17], происходят те или иные изменения в его «ситуации социального развития». Кризис «семилетнего возраста» больше, чем какой-либо, чреват опасностью нарушений произвольной регуляции. Этот вывод подтверждается многочисленными исследованиями, авторы которых находят, что, при относительном благополучии сферы когнитивной, в эмоциональной преобладают такие серьезные отклонения, как повышенная тревожность, страх перед новым микросоциумом, девиантность поведения. Работа педагогов в сфере коррекции таких когнитивных процессов, как развитие памяти, концентрация внимания, мало что дает в силу того, что в общей картине проявления нарушений произвольной регуляции доминируют поведенческие, а не иные проблемы [4, С.27-45].

Высокий уровень тревожности, который диагностируется у большинства описываемых детей, школьные страхи, поведенческие проблемы становятся основными препятствиями в устранении причин нарушений произвольной регуляцией деятельности, в то время как коррекционная работа с детьми строится по типу «репетиторство в школе» - дополнительные занятия по основным школьным предметам [5, С.31-33]. Получается замкнутый круг: дополнительные занятия с учителем, работа психолога, направленная на коррекцию когнитивных процессов, еще больше усиливают влияние патологических факторов, повышают истощаемость и, как следствие, еще большее отставание уровня физического, эмоционального и интеллектуального развития их слышащих сверстников. 
Говоря об особенностях физического развития слабослышащих детей, обратим внимание на нарушения моторики в сравнении с моторикой здоровых детей. В литературе, как правило, отмечается шаркающая походка слабослышащих детей, неуклюжесть бега на полусогнутых ногах при малой амплитуде движений рук и незначительном наклоне туловища.

Сами движения лишены пластичности, они не уверенны и не точны, наблюдается асимметрия шагов, пошатывания корпуса, повышенная резкость движений. Отсутствие словесного общения в процессе формирования движений также является одной из причин, снижающих качество движений.

Сформированные же движения характеризуются нарушением координации, ориентировки в пространстве, боязни высоты, замедленности движений. Слабослышащие дети часто не только не умеют бегать - они не умеют прыгать, лазать, подражать простейшим движениям взрослых [5, C.18-21].

Для дошкольников с нарушенным слухом характерны мышечная слабость, снижение тонуса мышц, вегетативные расстройства. В группе детей с нарушениями слуха отмечаются большие индивидуальные различия внутри одной возрастной группы [6, С.13].

Нарушение слухового восприятия вызывают специфические изменения в снижении двигательной памяти, произвольного внимания, особенно $\mathrm{y}$ учащихся младшего и среднего школьного возраста. Многие неслышащие школьники с трудом осваивают представления о мерах времени и об отношениях между единицами измерения.

Слух теснейшим образом связан с движением. Н.А. Бернштейн, указывая на взаимосвязь двигательного и слухового анализатора, подчеркивал, что движение корректируется не только зрением, но и слухом [7, С.23].

Вместе с тем в физическом и моторном развитии таких дошкольников отмечаются тенденции, характерные для слышащих детей.

Таким образом, очевидно, что коррекция нарушений двигательной активности слабослышащих детей является, наряду с другими сторонами воспитания и обучения, одним из важных направлений коррекции нарушений произвольной регуляции слабослышащих детей - старших дошкольников. Не нуждается в особых доказательствах аксиома, по которой правильно организованная коррекция нарушений двигательной активности слабослышащих детей становится базой для их успешного развития и в сфере познавательной деятельности. 
В специальной литературе предлагается, уделяя особое внимание развитию двигательной активности, формировать произвольное внимание, умение подражать простейшим действиям взрослого, развитию эмоциональноволевой сферы. Общеизвестны рекомендации по обучению слабослышащих детей-дошкольников ходьбе, бегу по показу воспитателя, включающего слабослышащих детей в процессе инклюзивных занятий в игровую деятельность.

Однако часто в этих рекомендациях не учитывается простая реальность, имеющая место в жизни слабослышащего ребенка - противоречие между пониманием взрослыми необходимости адаптивного физического воспитания детей нарушениями слуха различной степени тяжести и весьма условной познавательной активностью данной категории детей.

Очевидно, что занятия по развитию двигательной их активности должны быть в то же время и занятиями по развитию активности познавательной. Но как построить занятия адаптивной физкультурой таким образом, чтобы слабослышащему ребенку было интересно, чтобы, помимо двигательной, активизировалась и познавательная деятельность? Нельзя же отрицать, что сложившаяся традиционная система адаптивных занятий физической культурой со слабослышащими детьми в разрешении сложившегося противоречия не особо преуспевает. Между тем, несформированность моторики и особенности развития психических функций ставят слабослышащих детей в специфические условия.

С потерей слуха значительно снижается объем речевой информации, которая участвует в формировании всех видов деятельности, в том числе в активизации познавательной деятельности. В связи с этим словесная речь является необходимым фактором при обучении физическим упражнениям и двигательным действиям в процессе физического воспитания, игровой и спортивной деятельности. П.Ф. Лесгафт рекомендовал все движения ребенка сочетать со словесным объяснением. Речевая инструкция ускоряет выработку условных рефлексов, формирование сложных двигательных навыков и делает их более стойкими. Речь, сопровождая все двигательные реакции, упорядочивает последние, преодолевает их диффузный, импульсный характер, делает их организованными и дифференцированными [8, С. 138].

Учеными доказано, что у слабослышащих детей страдает не только произвольная регуляция (речевая и связанная с нею познавательная деятельность), но и эмоциональное развитие также имеет свою специфику. В 
частности, Т.М. Грабенко, И.А. Михаленкова отмечают неполноценность эмоционального общения, непосредственно связанного с нарушениями речевой деятельности [См. 9, С.9-12]. Слабослышащему ребенку, даже если он растет в благополучных социально-педагогических условиях, практически недоступна речевая экспрессия, играющая столь важную роль в межличностном общении подростков. Следовательно, данная категория детей, не умеющих в силу своей патологии дифференцировать эмоциональную окрашенность речи своих нормально слышащих сверстников, остается в их среде в лучшем случае чужаком, часто - изгоем.

В педагогической практике автору статьи приходилось сталкиваться с откровениями младших школьников без данной патологии: их межличностные конфликты с слабослышащими сверстниками, чаще всего выливающиеся в девиантную модель поведения («мы их бьем»), основаны далеко не всегда на жестокости тех, кто здоров. Последними, как это ни звучит парадоксально, руководит страх того, что «они (слабослышащие) не такие, мы их боимся». В свою очередь, и у детей с сенсорными нарушениями ряд ученых (Н.В. Мазурова, В.М. Акимушкин) указывают на наличие повышенной тревожности, неврозов, страхов, поскольку слабослышащие и используют все органы чувств для восприятия информации, но эта информация является неполной и неточной. А это - предпосылки девиантного поведения, так как часто своеобразие взаимоотношений слабослышащих детей со своими слышащими сверстниками выражаются в вспыльчивости, агрессивности, замкнутости, особой субкультуре слабослышащих [См. 10, С.91-102].

Но комплексных исследований в этой области практически нет, в то время как доказывать значимость проблемы, по сути, нет нужды - она очевидна как в психологическом, так и в социальном плане. Свести к минимуму психологический дискомфорт, негативные, травмирующие личность переживания, сопряженные с внутренними или внешними конфликтами, важно не только для детей с нарушением слуха, но и для современного социума в целом.

Автор понимает, что вопрос о роли родителей в выстраивании отношений слабослышащего ребенка с окружающим миром - тема специального исследования. В контексте данной статьи следует заметить, что прежде всего они должны научиться воспринимать ребенка таким, какой он есть, с любовью, а не в стремлении «прогнуть мир под себя», упрямо не соглашаясь с тем, что их дитя - особенное. Говоря словами известного героя Михаила Булгакова, 
«разруха», в том числе и психического свойства, «начинается в голове». Адекватно оценить состояние ребенка с сенсорными нарушениями, окружить его любовью и теплотой, не стыдиться его «изъяна», а помочь стать таким, чтобы им можно было гордиться - нелегкий родительский труд, но иного пути в выстраивании отношений социума с слабослышащими детьми, в преодолении психологических комплексов последних просто не существует. В противном случае дефект слуха и связанное с ним нарушение произвольной регуляции может стать причиной неразрешимых эмоциональных и социальных проблем. Неспособность понимать то, что говорят другие люди, может привести к чувству изоляции, одиночеству и депрессии, озлобленности и деструктивному протесту против всех и вся.

«Комплекс инвалидности» - вещь для слабослышащего ребенка опасная во всех отношениях. Особенно в условиях современного инклюзивного образования, призванного решить проблемы социализации учащихся с ограниченными возможностями здоровья, к категории которых относятся и слабослышащие дети. Их социальная адаптация определяется не только (и, смеем заметить - не столько) степенью дефекта слуха, а в первую очередь особенностями их поведения. Вскользь заметим, что имеем в виду эмоциональный интеллект: инструмент для успешного освоения социума с помощью эмоций как особого вида познания [11, С. 22-26..]. Впрочем, и он остается в решении проблемы преодоления психологических комплексов слабослышащих подростков пока явлением малоизученным.

Заметим лишь, что проблема эмоционального интеллекта активно рассматривалась зарубежными учеными, такими, как Дж. Мейер, П. Сэловей, Д. Карузо, Д. Гоулман, Р. Бар-Он, Д Слайтер, Х. Вейсингер, Р. Стенберг, Дж. Блоки др.) и отечественными учеными (Л.С. Выготский, С.Л. Рубинштейн, А.Н. Леонтьев, А.Р. Лурия, Б.В. Зейгарник, О.К. Тихомирова, Д.В. Ушаков, Д.В. Люсин, И.Н. Андреева, С.П. Деревянко, О.А. Гулевич, В.В. Овсянникова, Е.А. Сергиенко, Т.А, Сысоева, О.В. Белоконь и др. [См 12, С. 264 - 278].

На взгляд автора, философия и техника движений в занятиях Киокусинкай в определенной мере способны разрешить сложившуюся дилемму. Автор считает, что это - проверенный веками инструмент коррекции психологического состояния слабослышащих детей, особенно если использовать его уже на стадии адаптивных занятий со слабослышащими детьми - старшими дошкольниками. Не вдаваясь подробно в суть вопроса, поскольку он - предмет отдельного исследования, отметим, что главный 
принцип всех восточных единоборств заключается в короткой фразе побеждает сильный духом.

Известно, что путь Дао ведет к духовному совершенствованию человека, которое осуществляется на тренировках, являющихся, по сути, активной медитацией. Автору показалось конструктивной идеей помочь слабослышащим детям в преодолении их психологических комплексов, основываясь на философии восточных единоборств прежде всего потому, что восточные единоборства включают в себя и лечебно-оздоровительное направление, и особую культуру, философию, главный принцип которой - не только победить противника, но и обрести гармонию, понять собственную сущность, совершенствовать нравственность, побеждая все дурное в себе, развиваться как физически, так и духовно.

И чем раньше начинать осваивать философию Киокусинкай, хотя бы в тех пределах, что доступны пониманию старшего дошкольника, тем больших успехов в психофизических тренировках, лежащих в основе занятий, можно достичь.

Философия же Киокусинкай во многом сводится к тому, чтобы вступивший на Путь Доу овладел искусством умерять в себе животные инстинкты, туманящие человеческий дух, воспитывать в себе достойное приятие выпадающих на жизненном пути трудностей.

Для слабослышащих детей, пытающихся защититься от жестокости внешнего мира с помощью агрессии, девиантного поведения, данное искусство, Кодекс чести воина, основанный на 7 принципах, может стать отправной точкой в его перерождении.

Не будем забывать и о том, что в восточных единоборствах практика тренировки тела без изменения сознания, воспитания духа невозможна: постепенно все мелкое, эгоистическое, агрессивное уходит, уступая место уравновешенности, доброжелательности, невозмутимости. Одна из истин восточных единоборств гласит: поднимать свой невидимый меч следует только в исключительных случаях, когда невозможно без этого обойтись.

В древней книге "Сокрытое в листве" писалось: "Направь мысли на путь, который ты предпочел и иди. Воспитывай свой разум. Твоя воля выполнит свой долг, твой щит превратится в стальной щит... [13, С.12]. Для нашего исследования важно и то, что восточные единоборства предполагают устойчивость традиций, тесную связь Учителя и ученика, поскольку первый является для второго не только тренером техники единоборства, но - прежде 
всего духовным наставником, учителем жизни. Здесь важна и прекрасная физическая форма ученика, и устойчивость его психики, формирование и развитие нравственных качеств личности.

Отметим еще одну важную особенность философии восточных единоборств, позволяющую слабослышащему подростку с изломами в психике, крайне низкой самооценкой обрести уверенность в себе, самоуважение. В восточных единоборствах вовсе не соревнования и результаты, показанные в них, являются среднесрочной и дальней целью тренировок. Вряд ли поспоришь с тем, что титул «победитель соревнований», пусть даже и многократный, вовсе не равнозначен понятию «непобедимый мастер, постигший суть философии единоборств». Равно как справедливо и то, что часто погоня за титулами чревата пренебрежением, а то и вовсе потерей духовных ценностей и краеугольных понятий философии восточных единоборств. В истинном единоборстве нет победителя, как нет и побежденного: любая победа относительна, исключение - лишь победа над собой, своими страхами и комплексами.

А этому учатся через практику единоборств Востока, руководствуясь незыблемым правилом: если у человека что-то болит, если природа «наградила» его серьезным сбоем в работе тех или иных органов, - лечить следует свой Дух [См. 14, С 106 - 107].

Кроме того, восточные единоборства - и Киокусинкай здесь не исключение - при систематических ими занятиях развивают способность принимать быстрые и взвешенные решения. А это умение полезно не только в момент «сражения», но и в любых жизненных обстоятельствах. В учебном поединке спарринг-партнерам приходится максимально включать логическое и критическое мышление, даже если они у слабослышащих детей находятся в состоянии, далеком от того, что являет собою мышление их здоровых сверстников. Привычка оценивать каждое движение не только в спарринге способствует коррекции двигательной активности слабослышащего ребенка, в то же время корректируя и нарушения его произвольной регуляции.

Важно и то, что в философии восточных единоборств, каковым является и Киокусинкай, неотъемлемой их чертой уроки самоконтроля, упражнения на контроль эмоций и душевного состояния. Учение моральным ценностям происходит благодаря интересным философским течениям. Они идут рука об руку с физикой тела. По данным Д.О. Труфанова, современные единоборства в целом оказывают позитивное влияние на личностные структуры практикующих 
их индивидов, продуцируя социально одобряемый тип личности. Как вид социальной деятельности, современные единоборства оказывают влияние на систему ценностных ориентаций занимающихся ими лиц, обусловливая характерные изменения в ней у практиков разного возраста, имеющих различный стаж занятий по разным направлениям единоборств. Институт восточных единоборств служит одним из факторов социализации человека, поэтому заслуживает пристального внимания. [15, С.42- 57].

В отечественной науке имеется несколько работ, посвященных восточным единоборствам. Выделить стоит работы авторов, обращающих особое внимание на философию, которая выходит за рамки «просто философии» и создает особую систему, формирующую сознание единоборца средствами китайской метафизики. Среди них стоит особо отметить востоковеда, писателя и переводчика Александра Долина и его кн. «Кэмпо истоки воинских искусств», где автор воссоздает основные этапы развития традиционных воинских искусств Востока как уникальной, не имеющей аналогов системы [16, С.129-134]. Высокую познавательную и методологическую ценность представляет работа, выполненная в рамках философии, - «Восточные единоборства как онтологическое явление» M.M. Ишмуратова, в которой дается комплексный анализ системы восточных единоборств, рассматриваются традиции единоборств от их зарождения до наших дней [17, С.28-31], а также работа, выполненная в рамках социальной философии - «Философско-педагогические аспекты боевых искусств Востока» Т.Е. Носовой.

В последней уделяется внимание социально-философскому осмыслению методологии и педагогическим традициям боевых искусств Востока, раскрывается специфика самосовершенствования личности [18, С.19-27].

Выделим также работу, выполненную в рамках педагогики: «Становление социально-педагогической системы единоборств и ее развитие в современных условиях» А.А. Передельского. Автору удалось разработать принципы построения социально-педагогической системы единоборств и внедрить ее в образовательный процесс [19, С.13-14]. В его диссертационном исследовании ключевой, на наш взгляд, стала мысль о том, что единоборства формируют мощный стимул для становления идеала целостной и жизнеспособной личности. Этот идеал объединяет в себе представления о таких фундаментальных функциях, как стремление к самосовершенствованию, самоконтролю, самозащите от агрессивных, разрушающих воздействий. 
Важное значение для понимания философских основ восточных видов единоборств имеют работы отечественных ученых-востоковедов: Н.В. Абаева, А.А. Долина, В.В. Малявина, А.А. Маслова. Фундаментальные основы китайской метафизики (на которой базируются все виды восточных единоборств) описаны в работах Л.С. Васильева, В.Е. Еремеева, А.М. Карапетьянца, А.И. Кобзева, А.Е. Лукьянова, А.С. Мартынова, Вэньданя Мо, Фэн Ю-ланя и др.

Однако, изучая вопрос, неизбежно приходим к выводу, что растущий поток специальных исследований, по сути, не проясняет сокровенного смысла внутреннего содержания восточных единоборств как науки жизни, в которой стремление человека к самосовершенствованию невозможно рассматривать в отрыве от окружающей среды, природной и социальной.

В то же время очевидно, что философия восточных единоборств в современной России является одним из признанных факторов социализации, обеспечивающей включение человека в общество. Аспект, безусловно, важный, особенно в контексте смены парадигмы ценностей, когда индивидууму самостоятельно приходится выстраивать их шкалу, позволяющую свободно и комфортно существовать в социуме. Взрослому человеку, не говоря уже о ребенке, порой сложно разобраться с ценностями - традиционными и настоящими. Непонятно, для чего жить, к чему стремиться, как отделить хорошее от плохого. Тем более - ребенку слабослышащему, который чаще всего склонен к перманентному конфликту с окружающими его людьми сверстниками и взрослыми.

Не находя ответа на эти и другие, не менее сложные вопросы, ребенок, взрослея, часто становится на путь девиантного поведения. Тем не менее, современное общество еще не осознало ни масштабов проблемы социализации, ни ее мощи, хотя не раз уже испытало беспокойство и озабоченность по поводу отдельных ее проявлений. В этой связи уместно будет заметить, что восточные единоборства в современном российском обществе успели стать частью, и весьма заметной, социальной реальности, хотя и трактуются чаще всего как особый, выделенный из нее феномен.

Как вид социальной деятельности, современные единоборства оказывают влияние на систему ценностных ориентаций занимающихся ими лиц, обусловливая характерные изменения в ней у практиков разного возраста, имеющих различный стаж занятий по разным направлениям единоборств $[15$, C.41-44]. 
К сожалению, приходится констатировать (автору это позволяет делать многолетняя не только спортивная, но и преподавательская практика), что далеко не все тренеры и преподаватели по восточным единоборствам имеют достаточные знания о философской, метафизической составляющей единоборств. А если и имеют, то недостаточно полно реализуют это на практике. В большинстве случаев все обучение сводится к формированию у учеников физических качеств, равно как и обучению техническим элементам, поскольку в современной российской традиции физического воспитания (с 90-х гг. 20 в. по настоящее время) тренеры готовят исключительно спортсменов, а не людей, имеющих сформированную систему ценностей, в то время как философские идеи всегда играли в восточных единоборствах решающую роль при воспитании личности единоборца. Впрочем, это дискуссионное утверждение - тема более глубокого научного исследования, и в данной статье автором обозначается лишь вскользь, тогда как авторская методика занятий Киокусинкай с целью коррекции нарушений произвольной регуляции у слабослышащих детей рассматривается более широко.

В данной методике преподавателю приходится решать как общие, так и частные задачи.

Так, например, общая задача «Совершенствовать способность к дифференцированию временных параметров движения» предполагает решение следующих частных задач:

-развивать способность к дифференцированию длительности всего движения;

-развивать способность к дифференцированию длительности отдельных фаз движения;

-развивать способность к дифференцированию темпа движения (рис.1).
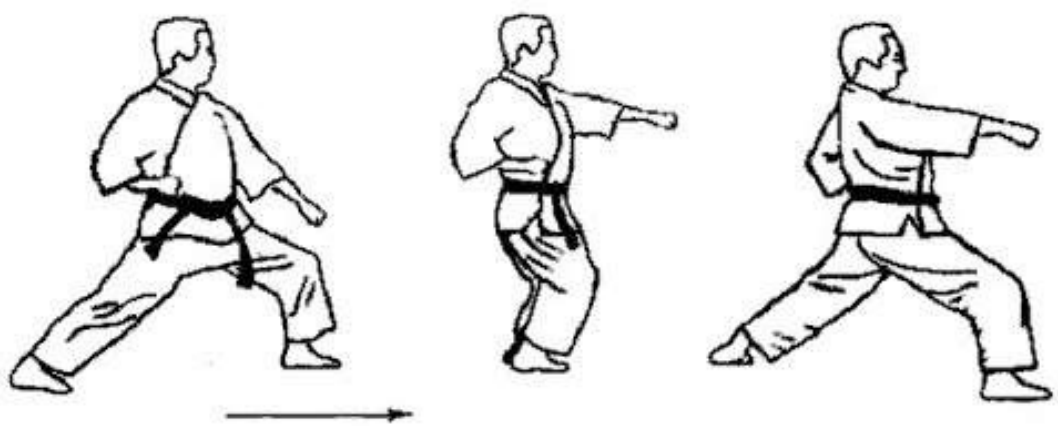

Рис. 1. 
Перемещение вперед в стойке дзенкуцу-дачи с выполнением удара одноименной рукой (ой-цуки). В данном варианте, выполняется по сигналу. Направление движения строго вперед. Для этого на полу необходимо сделать отметки, предварительно отмерив шаг и определив длину стойки. Для правильного выполнения двигательного действия необходимо при обучении использовать расчлененно-конструктивный метод.

На первом этапе ученик выполняет только шаг (перемещение вперед в стойке дзенкуцу-дачи), стараясь попасть точно по отметке на полу. Также он следит за положением тела, которое должно быть строго вертикально, а бедра и корпус должны оставаться фронтально по отношению к цели. Шаг выполняется в две стадии. Первая стадия заключается в резком подтягивании ноги, находящейся сзади к передней ноге. Вторая, в выставлении той же ноги вперед с переносом веса тела на указанную ногу.

Второй этап заключается в овладении учеником таким действием как «прямой удар рукой со сжатым кулаком» (цуки). Для правильного выполнения данного действия необходимо ровно встать в позицию напоминающую «стойку ноги врозь»

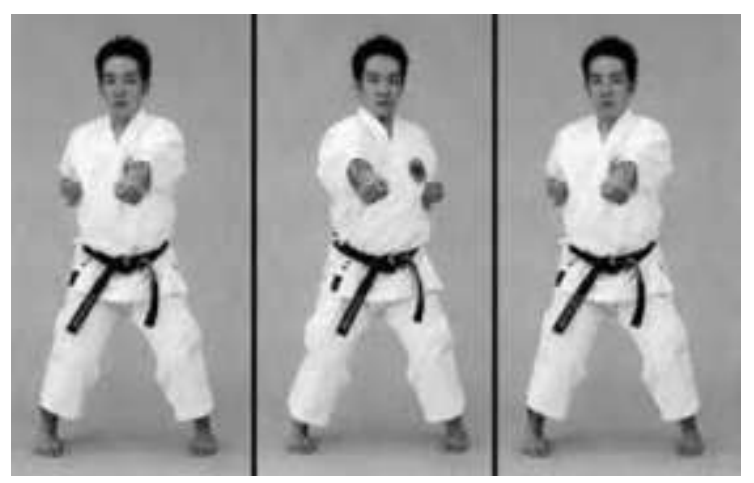

\section{Стойка ноги врозь}

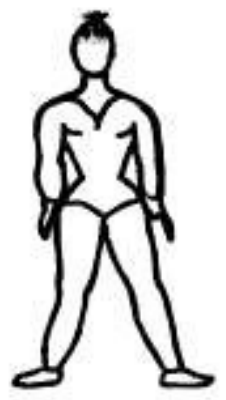

\section{Pис. 2.}

В Киокусинкай данная позиция называется «Фудо-дачи» Отличительная особенность данной позиции будет заключаться в положении стоп. Они должны быть расположены параллельно и повернуты носками вперед.

Удар рукой выполняется вперед в центр. Кулак переворачивается тыльной стороной вверх по мере приближения к цели. Вторая рука выполняет движение назад, уходя локтем за спину. В конечном положении кулак разворачивается тыльной стороной вниз. (Рис.2) 
При выполнении данной техники очень важно следить за тем, чтобы не появлялись дополнительные векторы движения, что будет значительно уменьшать скорость выполнения технического действия и, как следствие, влиять на силу удара в конечной точке.

После овладения вышеуказанными двигательными действиями (перемещение в стойке дзенкуцу-дачи и выполнение прямого удара рукой со сжатым кулаком «цуки»), можно переходить к следующему этапу.

Третий этап заключается в соединении данных движений и дифференцированию длительности отдельных фаз. Удар рукой «цуки» начинается позже и заканчивается одновременно с постановкой ноги, т.е. с приходом в конечную позицию (стойку дзенкуцу-дачи). Очень важно, чтобы ученик запомнил статическое положение в начальных и конечных фазах движения. Также при обучении используется метод, в котором ученик делает дополнительную остановку в промежуточной фазе (как на рисунке 1). Это необходимо для контроля положения тела во время перемещения. В дальнейшем эта остановка не используется.

После освоения учеником этого действия и расстановки акцентов можно переходить к следующей части методики, выполнению шагов (перемещений в стойке дзенкуцу-дачи) с ударами одноименной рукой (ой-цуки).

Ученик принимает исходное положение и готовится совершить перемещение с ударом по сигналу с максимальной скоростью, строго в указанном направлении. Сигналом может служить громкий хлопок, свисток или удар мячом об пол. При этом преподаватель должен располагаться сзади, чтобы ученик не видел его, а ориентировался только на звук. Сигналы должны подаваться с разной частотой. Это очень важно, так как ритмичность в этом упражнении категорически противоречит смыслу выполнения данных действий по сигналу. Для наилучшего развития быстроты рекомендуется добавлять в это упражнение соревновательный момент. В шеренге располагается несколько учеников, которые по звуковому сигналу выполняют одинаковые действия и шаги, стремясь обогнать, друг друга.

Количество шагов в дорожке не регламентировано и определяется длиной зала. В конце дорожки выполняется поворот и те же шаги (перемещения в стойке дзенкуцу-дачи с ударом одноименной рукой «ой-цуки») осуществляются в противоположную сторону (Рис.3- 4). 


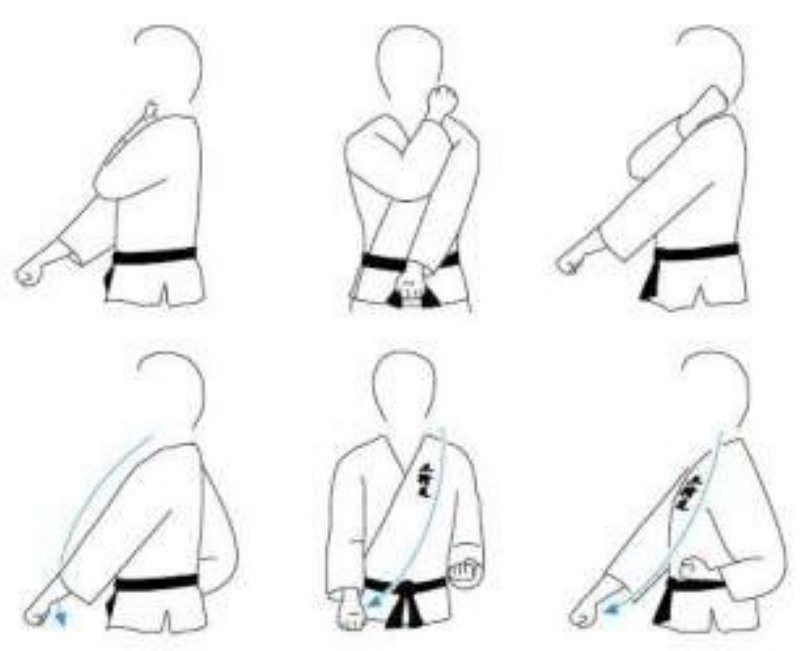

Рис. 3.

Рис. 4.

В момент поворота выполняется техническое защитное действие, называемое в Киокусинкай «блок». Конкретно в данном случае выполняется «нижнее сбивание» «гедан-барай» (рисунок 4). Одновременно с поворотом корпуса и переносом веса тела с одной ноги на другую, одноименной рукой осуществляется «нижнее сбивание».

Для освоения этого двигательного действия используется также расчлененно-конструктивный метод. Отдельно в позиции «фудо-дачи» выполняется «блок гедан-барай».

Отдельно также осваивается и поворот в стойке и перенос веса с ноги на ногу. Поворот осуществляется на 180 градусов, то есть строго в противоположном направлении.

На следующем этапе необходимо освоить несколько видов поворотов и перемещений.

Первый поворот выполняется из исходного положения «фудо-дачи» (стойка ноги врозь). Действие начинается с поворота головы в направлении движения. Затем, занижая центр тяжести, необходимо отставить левую ногу под углом 90 градусов влево. Ступню левой ноги плотно поставить на пол, носок повернуть по направлению движения. Перенося вес тела с правой на левую ногу, осуществить поворот корпуса. Вместе с тем выполняется левой рукой защитное действие (нижнее сбивание) «гедан-барай». Действие рукой начинается позже и заканчивается одновременно с поворотом тела и переносом веса на левую ногу, то есть одновременно с приходом в стойку. 
Следующий поворот выполняется из исходного положения стойка «дзенкуцу-дачи» с выставленной правой ногой вперед (правосторонняя). Необходимо повернуться на 180 градусов с переносом веса тела и оказаться в такой же правосторонней стойке, только в противоположном направлении. Для этого нужно из исходного положения подтянуть правую ногу к левой, затем отставить ее назад в направлении предстоящего поворота. Используя образовавшееся скручивание в пояснице, резким движением повернуть корпус на 180 градусов и зафиксировать тело в конечном положении. При выполнении данного двигательного действия корпус остается в вертикальном положении. Очень важно определить момент, в который происходит поворот головы так как голова поворачивается раньше, чем происходит перенос веса и разворот корпуса. Таким образом, поворот головы и взгляд определяют направление движения. Так же, как и в предыдущем повороте, руками выполняется защитное действие (нижнее сбивание) «гедан-барай». В момент подтягивания правой ноги к левой руки принимают исходное положение для выполнения «блока». При развороте корпуса, за счет возникающей центробежной силы, выполнение блока «гедан-барай» не требует дополнительных усилий, а осуществляется только за счет инерции.

Третий поворот выполняется из исходного положения стойка «дзенкуцудачи» с выставленной левой ногой вперед (левосторонняя). Поворот осуществляется под углом 90 градусов относительно направления стойки в исходном положении. Для этого в исходном положении вес тела смещается назад, на правую ногу, разгружая левую. Затем происходит поворот головы, определяющий направление. После чего левая нога выставляется в сторону под углом 90 градусов. Завершающим действием будет являться перенос веса на левую ногу и разворот корпуса по направлению 90 градусов относительно исходного положения. Вместе с тем, как и в предыдущих случаях, при повороте выполняется защитное действие «гедан-барай». В момент выставления левой ноги руки принимают исходное положение, а при переносе веса выполняют непосредственно сбивание. Окончание движений руками совпадают с приходом в конечное положение всего тела.

Следующий, четвертый поворот, выполняется из исходного положения стойка «дзенкуцу-дачи» с выставленной правой ногой вперед (правосторонняя). Поворот осуществляется на 270 градусов, через спину. На схеме данное действие является переходом из точки 8 в точку 9. Левая нога, находясь сзади, перемещается вправо. Голова поворачивается через левую сторону на 270 
градусов. Руки принимают исходное положение для выполнения защитного действия «гедан-барай». Когда левая нога находит точку, необходимую для образования правильной, устойчивой конечной позиции, происходит поворот корпуса за счет скручивания и натяжения, образовавшегося в пояснице. Возникающая центробежная сила дает инерцию для выполнения защитного действия руками «гедан-барай» и не требует дополнительных усилий.

После освоения всех вышеуказанных поворотов, перемещений в стойке, четкого определения направлений движения можно перейти к методу строго регламентированного упражнения. Все ранее изученные действия объединяются в одном упражнении. Данное упражнение в Киокусинкай называется «Тайкеку соно ити» и имеет очень важное значение в начальной подготовке спортсмена. А также является неотъемлемой частью программы обучения «каратиста» так как в нем заложены основные движения, необходимые для дальнейшего изучения Киокусинкай как стиля каратэ.

По своей сути «Тайкеку соно ити» является «ката» и относится к разделу «простейших ката» Киокусинкай.

КАТА - формализованная последовательность движений, связанных принципами ведения поединка с воображаемым противником или группой противников. Изучение и отработка «ката» является основным тренировочным методом в каратэ.

На следующем рисунке представлена схема движения и шагов в «Тайкеку соно ити». В данном упражнении присутствуют повороты в различных направлениях, которые выполняются вместе с защитными действиями и перемещения в стойке (шаги) с прямым ударом рукой со сжатым кулаком (ойцуки). Все технические действия в данном упражнении выполняются одноименной рукой по отношению к выставленной вперед ноге. Положение корпуса строго вертикально. Выполнение данного упражнения на начальном этапе производится по разделению, т.е. каждый шаг выполняется под счет или по звуковому сигналу. Затем преподаватель меняет темп, как всего упражнения, так и отдельных его частей. В «тайкеку соно ити» присутствуют два акцентированных действия. В момент исполнения которых, занимающийся производит громкий выкрик одновременно с ударом (Рис.5). 


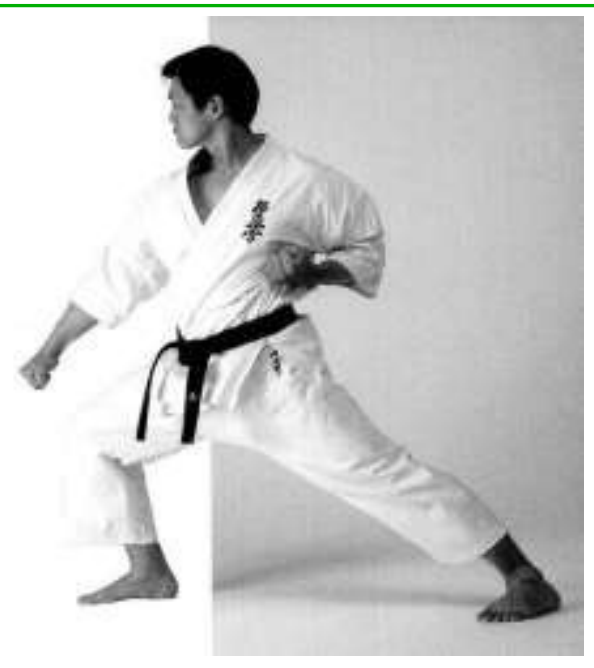

Рис. 5.

На следующем этапе обучения вся форма «Тайкеку соно ити» выполняется занимающимся самостоятельно. Преподаватель дает команду к началу выполнения упражнения: «Тайкеку соно ити, йой! Хаджимэ». При самостоятельном исполнении занимающийся должен соблюдать определенный темпоритм.

После шага $(1,3,9,11,17,19)$ производится пауза, условно в одну темпоритмическую единицу, а после шагов $(2,4,5,10,12,13,18)$ необходимо сделать паузу в две темпоритмические единицы. Шаги $(6,7,8)$ а впоследствии $(14,15,16)$ выполняются подряд, не имея ритмических остановок между собой. Удар, выполняемый на 8, также как и на 16 шаг, акцентирован. Одновременно с ним производится громкий выкрик. В Киокусинкай данное действие называется «Ки-яй». После чего производится пауза в три темпоритмические единицы. После 20 шага выдерживается самая большая пауза, условно она длится пять темпоритмических единиц.

Если рассматривать техническую составляющую упражнения, то в «Тайтеку соно ити» происходит чередование защитных и атакующих действий, то есть сочетание «блоков» и ударов. Таким образом, шаги, представленные на схеме под номерами $(1,3,5,9,11,13,17,19)$ выполняются одновременно с защитным действием «гедан-барай» (нижнее сбивание), а $(2,4,6,7,8,10,12,14,15,16,18,20)$ выполняются одновременно с атакующим действием «ой-цуки» (прямой удар рукой со сжатым кулаком).

Для более точного определения направлений и длины шага, при обучении используется разметка на полу. Но, учитывая разницу антропометрических 
показателей, длина шага у каждого занимающегося будет отличаться, поэтому разметку необходимо делать индивидуально.

После освоения данного упражнения, устранения грубых ошибок, связанных с нарушением «рисунка», последовательности защитных и атакующих действий, а также закрепления определенного ритма при выполнении упражнения, меняются условия выполнения некоторых действий. Шаги $(2,4,6,7,8,10,12,14,15,16,18,20)$ выполняются с поворотом на 270 градусов через спину. При этом занимающийся производит эти действия на той же разметке и обязан попасть ногой на указанное ранее место.

При нарушении произвольной регуляции в особом подходе нуждаются процессы контроля за собственным выполнением. Как правило, дети с трудностями произвольной регуляции не замечают и не исправляют самостоятельно своих ошибок. Им свойственна торопливость и некоторое снижение критики в отношении того, что они делают. Именно с этой целью необходимо выполнять все шаги в вышеуказанном упражнении по предварительной, индивидуальной разметке на полу.

Необходимо останавливаться и концентрировать внимание на этапе самопроверки.

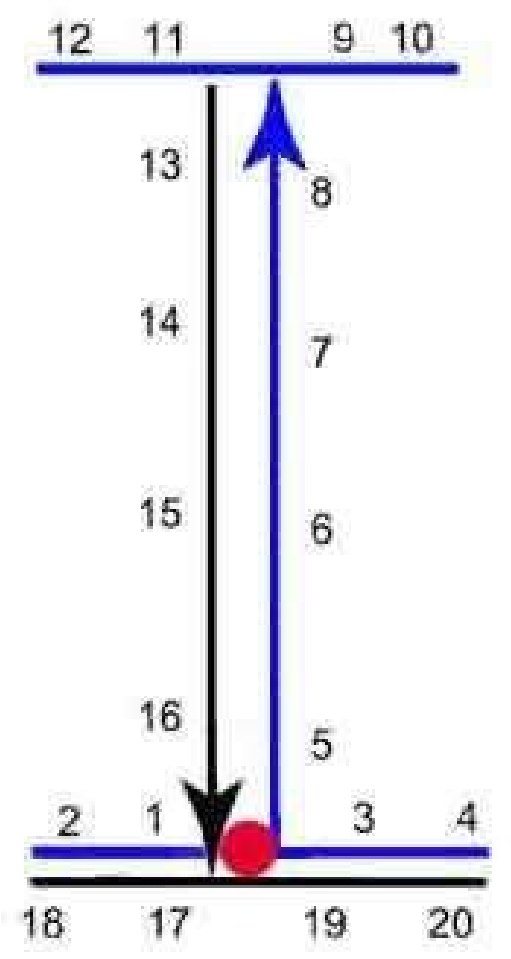




\section{Список литературы}

1. Специальная психология: Учеб. пособие для студ. высш. пед. С718учеб. заведений / В.И. Лубовский, Т. В. Розанова, Л. И.Солнцева и др.; Под ред. В.И. Лубовского. - 2-е изд., испр. - М.: Издательский центр «Академия», 2005. - 464 с.

2. Леонтьев А.Н. Развитие высших форм запоминания // Избранные психологические труды в двух томах, том 1 / Под ред. В.В. Давыдова, В.П. Зинченко, А.А. Леонтьева, А.В. Петровского. - М.: Педагогика. - 1983. 391 c.

3. Выготский Л.С. Орудие и знак в развитии ребенка // Собрание сочинений в 6 томах. - Т.6. - М.: Педагогика. - 1984. - 397 с.

4. Обухова, Л.Ф. Детская психология: теория, факты, проблемы / Л.Ф. Обухова. - Тривола, М., 1995. - 360 с.

5. Кутьин, И.В. Особенности работы с детьми младшего школьного возраста с нарушениями произвольной регуляции деятельности / И.В. Кутьин, С.А. Ткаченко, С.Н. Попов, И.В. Холмогорова // ХІІ Международный научный конгресс «Современный Олимпийский и Паралимпийский спорт и спорт для всех»: Материалы конгресса. - М.: Светотон, 2009, - Т.4. - С. 31-33.

6. Коржова А.А. Физическое воспитание детей с нарушениями слуха // Дошкольное воспитание аномальных детей / Под ред. Л.П. Носковой. - М., 1993.- 182 c.

7. Трофимова Г.В. Развитие движений у дошкольников с нарушениями слуха - М., 1979. - 240с.

8. Бернштейн Н.А. О ловкости и ее развитии /Н.А. Бернштейн; Под редакцией И.М. Фейгенберга. - М.: Физкультура и спорт, 1991. - 287 с.

9. Шапкова, Л.В. Функции адаптивной физической культуры: Учебное пособие / Л.В. Шапкова. - СПб.: СПбГАФК им. П.Ф. Лесгафта, 2012. - 82 с.

10. Грабенко Т.М., Михаленкова И.А. Эмоциональное развитие слабослышащих школьников: диагностика и коррекция. СПб.: Речь, 2008. 256 c.

11. Специальная психология: Учеб. пособие для студ. высш. пед. С718учеб. заведений / В. И. Лубовский, Т. В. Розанова, Л. И. Солнцева и др.; Под ред. В.И. Лубовского. - 2-е изд., испр. - М.: Издательский центр «Академия», 2005. - 464 с.

12. Андреева, И.Н. Понятие и структура эмоционального интеллекта[Текст] // В 2 ч. Смоленск: СГПУ- 2004. Ч. 1. - 388 с. 
13. Люсин, Д.В. Современные представления об эмоциональном интеллекте // Социальный интеллект: Теория, измерение, исследования [Текст]/ под ред. Д.В. Люсина, Д.В. Ушакова. М.: Институт психологии РАН, 2004. 176 с.

14. Цунэтомо Ямамото. Хагакуре. Сокрытое в листве. Кодекс чести самурая / Перевод: Р. Котенко, А. Мищенко. М., Издательство: Центрполиграф, 2016 -315 с.

15. Да лай-Лама. 365 медитаций на каждый день. - М.: Яуза, ЭКСМО, 2007. - 317 c.

16.Труфанов Д. О. Ценностная социологическая концепция современных единоборств: монография / Д.О. Труфанов. - Красноярск: РИО КрасГУ, 2006. 129 c.

17. Долин А.А. Кэмпо - истоки воинских искусств, издательство Ипполитова, 2008. - 720 с.

18. Ишмуратов М.М. Восточные единоборства как онтологическое явление: Дис. ... канд. филос. наук : 09.00.01. Уфа, 2004. - 143 с.

19.Носова Т.Е. Философско-педагогические аспекты боевых искусств Востока: Дис. ... канд. филос. наук : 09.00.01. Архангельск, 2006. - 150 с.

20.Передельский А.А. Становление социально-педагогической системы единоборств и ее развитие в современных условиях : диссертация ... доктора педагогических наук : 13.00.08. Москва, 2008. - 388 с. 